\title{
PERANCANGAN PILOT PLANT PENGOLAHAN AIR MINUM UNTUK ZONA PENDIDIKAN DAN RISET KAWASAN TECHNO PARK, KABUPATEN PELALAWAN
}

\author{
Judul Dalam Bahasa Inggris Ditulis Di Sini (Titlecase, Center, Regular, Font Calibri 10) \\ Taty Hernaningsih \\ Pusat Teknologi Lingkungan Badan Pengkajian dan Penerapan Teknologi
}

\begin{abstract}
Abstrak
Pembangunan daerah Techno Park adalah dalam rangka meningkatkan daya saing daerah berbasis pada inovasi dan pengetahuan (knowledge based economy) membutuhkan infrastruktur yang dapat memenuhi kebutuhan dasar manusia, seperti penyediaan air minum bagi masyarakat. Tekno Park Pelalawan di Provinsi Riau terletak di lahan gambut sehingga sebagian besar sumber air kecoklatan dan mengandung gambut. Sementara sumber air permukaan seperti sungai Kampar terletak jauh dari wilayah tersebut. Oleh karena itu, untuk mengatasi masalah pasokan air bagi orang-orang yang akan hidup di wilayah ini perlu dipersiapkan perencanaan pasokan air. tahap awal pengembangan difokuskan pada bidang pendidikan dan zona penelitian sehingga perencanaan untuk penyediaan air juga akan diprioritaskan di kedua zona tersebut. Telah dilakukan perhitungan kebutuhan air minum berdasarkan proyeksi populasi dan standar kebutuhan air di lokasi tersebut. Perencanaan instalasi pengolahan air dilakukan untuk 5 tahapan tahunan sehingga pembangunan lebih ekonomis dengan kapasitas desain 5 I/ detik di 2033. Alternatif sumber air baku berasal dari sungai Kampar atau air tanah yang digunakan jika pipa transmisi dari sungai Kapuas belum dibangun. Teknologi pengolahan air minum dengan proses ultrafiltrasi yang ramah lingkungan akan diterapkan untuk memenuhi kebutuhan air masyarakat. pipa transmisi direncanakan dari diameter 15 inci diletakkan secara paralel dengan jalur dari Sungai Kampar (lokasi intake BPAB) ke pabrik pengolahan air di zona pendidikan.
\end{abstract}

Kata kunci: Daerah taman techno, perencanaan pasokan air, ultrafiltrasi, lahan gambut.

\begin{abstract}
Techno Park regional development in order to increase regional competitiveness based on innovation and knowledge (konwledge based economy) requires infrastructure that can meet basic human needs, such as drinking water supply for the community. Techno Park region Pelalawan, Riau province located in the peat so that most of the water source is brownish and contains peat. While surface water sources such as rivers Kampar located far from the region. Therefore, to overcome the problems of water supply for the people who will live in the region need to be prepared water supply planning. Early stages of development is focused on the areas of education and research zone so that planning for water supply will also be prioritized in both these zones. Has calculated the drinking water needs based on projected population and water demand standard in these locations. Planning of water treatment plant will conduct in 5 stages yearly so that development is more economic with design capacity of $5 \mathrm{I} / \mathrm{sec}$ in 2033. Alternative sources of raw water are from Kampar river or groundwater that is used if transmission pipeline from the Kapuas river has not ben constructed. Technology of drinking water treatment with ultrafiltration processes that are environmentally friendly will be applied to meet the water needs of society. Transmission pipelines is planned of 15 inches diameter laying in parallel with lane highway from Kampar River (location intake BPAB) to the water treatment plant in the education zone.
\end{abstract}

Keywords : Techno park region, water supply planning, ultrafiltrasi, peat area. 


\section{PENDAHULUAN}

Dalam pengembangan kawasan Techno Park guna peningkatan daya saing daerah berbasis inovasi dan ilmu pengetahuan (konwledge based economy) yang melibatkan peran Pemerintah Daerah, perguruan tinggi, lembaga riset, dan industri memerlukan sarana infrastruktur yang dapat memenuhi kebutuhan dasar manusia. Diantara kebutuhan tersebut yang paling vital harus dipenuhi adalah air minum.

Sesuai dengan keadaan tersebut maka salah satu dari kawasan Techno Park yang sedang dikembangkan saat ini adalah kawasan Techno Park di kabupaten Pelalawan. Kawasan ini juga belum terbangun dan belum ada sarana kebutuhan dasar masyarakat seperti bidang penyediaan air minum.

Kawasan Techno Park Pelalawan terletak di daerah gambut sehingga sebagian besar sumber airnya berwarna kecoklatan dan mengandung gambut. Sedangkan sumber air permukaan seperti sungai Kampar lokasinya jauh dari kawasan tersebut.

Untuk memenuhi kebutuhan air di perkembangan kawasan tersebut maka harus disediakan air minum dengan kuantitas yang cukup dan kualitas yang memenuhi syarat serta terjamin kontinuitasnya. Meskipun alam telah menyediakan air dalam jumlah yang cukup, tetapi dengan adanya pertambahan penduduk dan peningkatan aktivitasnya telah mengubah tatanan dan keseimbangan air di alam. Sebagian besar air yang tersedia tidak lagi layak dikonsumsi secara langsung dan memerlukan pengolahan supaya air dari alam layak dan sehat untuk dikonsumsi. Oleh karena itu mengatasi permasalahan penyediaan air minum untuk masyarakat yang akan tinggal di kawasan Techno Park perlu disiapkan perencanaan penyediaan air minum yang memadai.

Dalam perencanaannya, kawasan ini dibagi atas beberapa zona sesuai dengan peruntukannya seperti, zona pendidikan, riset, pemukiman, industri, hutan lidung, komersial dan jasa. Peta zonasi kawasan Techno Park Pelalawan dapat dilihat pada gambar 1.

Tahap awal pengembangan kawasan ini difokuskan pada zona pendidikan dan riset sehingga perencanaan penyediaan air minum juga akan diutamakan pada kedua zona tersebut.

\subsection{Tujuan Dan Sasaran Kegiatan}

Tujuan utama kegiatan ini adalah untuk mengetahui menghitung jumlah kebutuhan air minum dan merencanakan Instalasi Pengolahan Air Minum zona Pendidikan dan Riset Kawasan Techno Park, Kabupaten Pelalawan.
Sasaran kegiatan perencanaan ini adalah menyediakan kebutuhan dasar manusia yang berupa air minum yang memenuhi standar kesehatan dengan jumlah yang cukup memadai.

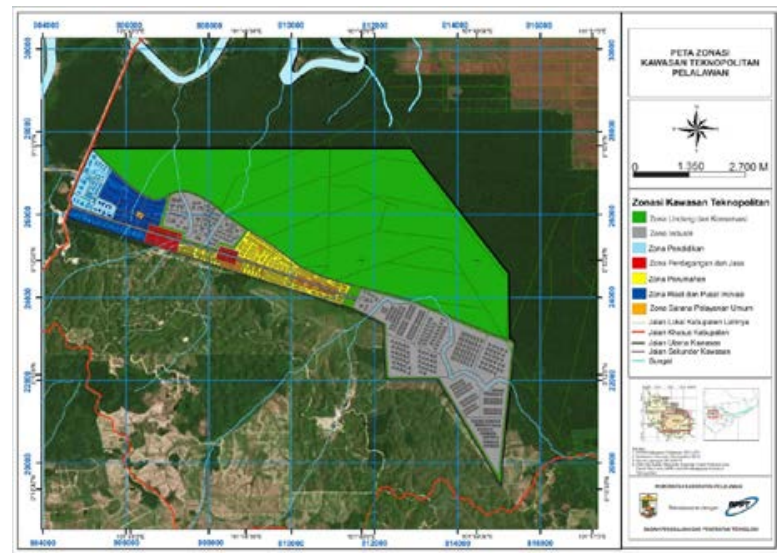

Sumber:

Master Plan Pengembangan Wilayah Kawasan Techno Park Pelalawan, BPPT, 2015

Gambar 1. Peta zonasi kawasan Techno Park Pelalawan

\subsection{Metodologi Kegiatan}

Dalam kegiatan ini, metodologi yang digunakan adalah sebagai berikut :

1. Observasi lapangan

2. Pengumpulan data primer dan sekunder

3. Pengolahan dan analisis data

4. Perencanaan pilot plant pengolahan air minum.

Pelaksanaan observasi lapangan yang dilakukan adalah berupa survai awal meliputi survai aksesibilitas untuk berbagai aktifitas, survai jarak, waktu, bahan baku, aspek fisik, sosial dan ekonomi. Ini dilakukan untuk mempersiapkan tahap selanjutnya sehingga pada tahap pengumpulan data akan diperoleh hasil maksimal.

Metoda pengumpulan data yang dilakukan dengan melakukan kunjungan ke Bappeda Pelalawan dan instansi terkait lainnya. Data primer juga didapat dari pelaksanaan survai persepsi masyarakat dan sosial-ekonomi dengan alat bantu kuesioner serta survai sumber air dan kualitas air.

Pengolahan dan analisa data hasil survai sosial ekonomi tersebut dilakukan dengan tahap dimana semua data yang sudah diperoleh/ditabulasi baik melalui survai maupun dari wawancara dimasukkan kedalam model database yang sudah dipersiapkan. Inti kegiatan dari tahap ini adalah menganalisis hasil survai dengan perhitungan secara statistik. Sedangkan hasil survai kualitas air dilakukan dengan mengirim sampel air ke laboratorium analisa air di 
kota Pekanbaru dan hasilnya akan dievaluasi sebagai sumber air baku pilot plant pengolahan air minum.

Selanjutnya dari dari data yang sudah diolah dan dianalisa serta disesuaikan dengan inovasi teknologi yang akan diterapkan maka dilakukan perancangan pilot plant pengolahan air minum untuk zona Pendidikan dan Riset Kawasan Techno Park, Kabupaten Pelalawan.

\section{KEBUTUHAN AIR MINUM}

\subsection{Penduduk Yang Dilayani Air Minum}

Secara garis besar, pelayanan air minum diutamakan di Zona Pendidikan dan Riset Kawasan Techno Park Pelalawan dengan perencanaan pelayanan dengan sistem perpipaan yang akan dikelola UPT PAB Pelalawan. Rencana Wilayah Pelayanan Air Bersih Zona Pendidikan dan Riset Kawasan Techno Park Pelalawan terdiri atas :

Wilayah pelayanan Zona Pendidikan untuk TK, SD, SMP, SMA, Akademi Kepolisian, ST2P, Bumi Perkemahan dan Akademi Komunitas dan Riset Kawasan Technopark Pelalawan

Wilayah pelayanan Zona Riset untuk Pusat Inovasi, Laboratorium Sapi Sawit, Perkantoran PPKS dan sisanya direncanakan untuk riset yang belum direncanakan.

Adapun jumlah mahasiswa, staf pengajar, teknisi dan staf dari zona pendidikan kawasan Techno Park Pelalawan yang dilayani air minum seperti pada Tabel 1 berikut.

Tabel 1. Jumlah Mahasiswa, Staf Pengajar Dan Teknisi Zona Pendidikan Kawasan Techno Park Pelalawan Tahun 2033

\begin{tabular}{|l|c|}
\hline \multicolumn{1}{|c|}{ PENDIDIKAN } & $\begin{array}{c}\text { JUMLAH } \\
\text { (Orang) }\end{array}$ \\
\hline Akademi kepolisian & 340 \\
\hline TK & 51 \\
\hline SD & 274 \\
\hline SMP & 286 \\
\hline SMA & 340 \\
\hline ST2P & 2926 \\
\hline Bumi Perkemahan & 550 \\
\hline $\begin{array}{l}\text { Akademi Komunitas (Maksimal 3 } \\
\text { Program Studi) }\end{array}$ & 321 \\
\hline Total & $\mathbf{4 7 5 8}$ \\
\hline
\end{tabular}

Sumber: Master Plan Pengembangan Wilayah Kawasan Techno Park Pelalawan, BPPT, 2015 dan Master Plan ST2P, 2013

Adapun jumlah SDM dari Zona Riset Kawasan Techno Park Pelalawan yang dilayani Air Bersih seperti pada Tabel 2 .

\subsection{Jumlah Kebutuhan Air Minum}

Jumlah air minum penduduk dihitung berdasarkan proyeksi jumlah penduduk5) dan kebutuhan air minum per orang per hari. Ada beberapa standar yang dapat digunakan untuk memperkirakan jumlah kebutuhan air minum di terapkan pada zona pendidikan dan riset.

Tabel 2. Proyeksi Jumlah SDM Di Zona Riset Kawasan Techno Park Pelalawan Tahun 2033

\begin{tabular}{|c|c|c|c|}
\hline $\begin{array}{c}\text { Sub Zona } \\
\text { Riset }\end{array}$ & $\begin{array}{c}\text { Luasan } \\
\text { (Ha) }\end{array}$ & $\begin{array}{c}\text { Proyeksi } \\
\text { SDM (Org) }\end{array}$ & Sumber \\
\hline $\begin{array}{l}\text { Pusat } \\
\text { Inovasi }\end{array}$ & 5 & 95 & $\begin{array}{c}\text { BIT:Kepada } \\
\tan : 95 \\
\text { org } / 5 \mathrm{Ha}\end{array}$ \\
\hline $\begin{array}{l}\text { Laboratoriu } \\
\text { m Sapi Sawit }\end{array}$ & & 10 & $\begin{array}{l}\text { PTPP } \\
\text { Kepadatan: } \\
10 \text { org/10 } \\
\mathrm{Ha}\end{array}$ \\
\hline $\begin{array}{l}\text { Perkantoran } \\
\text { PPKS }\end{array}$ & 10 & & \\
\hline Total & & 105 & \\
\hline
\end{tabular}

Sumber: Master Plan Pengembangan Wilayah Kawasan Techno Park Pelalawan, BPPT, 2015

\section{1) Fasilitas Zona Pendidikan}

Untuk kebutuhan air pada fasilitas zona pendidikan Kawasan Techno Park Pelalawan didasarkan atas peraturan PPSAB, Jawa Barat ${ }^{3)}$ dengan kebutuhan air yang diperhitungkan sebesar 15 - 30 liter/orang/ hari. Kebutuhan air Sekolah (SD - Universitas) 40 - 80 liter/murid /hari menurut SNI 03-7065-2005 sehingga untuk memperkirakan jumlah kebutuhan air di zona ini digunakan standar kebutuhan air 30 l/orang/hari.

Sesuai dengan kriteria kebutuhan air tersebut maka dihitung proyeksi kebutuhan air zona pendidikan kawasan Techno Park Pelalawan disajikan pada Tabel 3 berikut ini.

Tabel 3. Proyeksi Kebutuhan Air Zona Pendidikan

Kawasan Techno Park Pelalawan tahun 2013-2033

\begin{tabular}{|c|c|c|c|c|c|}
\hline \multirow{2}{*}{ No } & \multirow{2}{*}{ Tahun } & Jumlah & \multirow{2}{*}{$\begin{array}{c}\text { Kebutuhan } \\
\text { Air }\end{array}$} & \multicolumn{2}{|c|}{$\begin{array}{c}\text { Jumlah Kebutuhan } \\
\text { Air }\end{array}$} \\
\cline { 5 - 6 } & & (jiwa) & (I/jiwa/hari) & (m3/hari) & /detik) \\
\hline 1 & 2013 & 2976 & 30 & 89,28 & 1,03 \\
2 & 2018 & 4725 & 30 & 141,75 & 1,64 \\
3 & 2023 & 5548 & 30 & 166,44 & 1,92 \\
4 & 2028 & 6255 & 30 & 187,65 & 2,17 \\
5 & 2033 & 7067 & 30 & 212,01 & 2,45 \\
\hline
\end{tabular}

Sumber:

Analisa BPP Teknologi, Nopember 2015 


\section{2) Fasilitas Zona Riset}

Fasilitas penyediaan air minum digunakan untuk melayani zona Riset yang meliputi kebutuhan untuk laboratorium dan perkantorannya di Kawasan Techno Park Pelalawan. Standar peraturan PPSAB, Jawa Barat untuk faktor yang diperhitungkan adalah untuk pegawai dengan kebutuhan air 40 liter/orang/hari. Standar kebutuhan air Peraturan Gubernur Provinsi DKI Jakarta Nomor 122 tahun 2005 yaitu 50 liter/orang/ hari. Kebutuhan air
Gedung Kantor 50 liter/pegawai/hari SNI 03-70652005 sehingga untuk memperkirakan jumlah kebutuhan air di zona ini digunakan standar kebutuhan air 40 l/orang/hari. Sedangkan untuk laboratorium tidak ada sehingga digunakan perkiraan 1 laboratorium perlu kebuthan air 2 $\mathrm{m}^{3} /$ unit/hari.

Berdasarkan standar kebutuhan air tersebut maka dilakukan proyeksi kebutuhan air Zona Riset dan Inovasi Kawasan Techno Park Pelalawan yang disajikan pada Tabel 4. berikut ini.

Tabel 4. Proyeksi kebutuhan air Zona Riset Kawasan Techno Park Pelalawan tahun 2018-2033

\begin{tabular}{|c|c|c|c|c|c|c|c|}
\hline No & Tahun & Jumlah & $\begin{array}{c}\text { Kebutuhan } \\
\text { Air }\end{array}$ & $\begin{array}{c}\text { Jumlah } \\
\text { Lab. }\end{array}$ & $\begin{array}{c}\text { Kebutuhan } \\
\text { Air }\end{array}$ & $\begin{array}{c}\text { Jumlah } \\
\text { Kebutuhan }\end{array}$ & $\begin{array}{c}\text { Jumlah } \\
\text { Kebutuhan } \\
\text { Air } \\
\text { (l/detik) }\end{array}$ \\
\hline 1 & 2018 & 791 & 40 & 1 & 2 & 33,65 & 0,389 \\
2 & 2023 & 1243 & 40 & 1 & 2 & 51,7 & 0,598 \\
3 & 2028 & 1844 & 40 & 1 & 2 & 75,75 & 0,877 \\
4 & 2033 & 2445 & 40 & 1 & 2 & 99,8 & 1,155 \\
\hline
\end{tabular}

Sumber:

Analisa BPP Teknologi, Nopember 2015

Dari perhitungan di atas maka jumlah kebutuhan air zona Pendidikan dan Riset dapat dilihat seperti pada tabel 5 berikut.

Tabel 5. Proyeksi kebutuhan air Zona Pendidikan dan Riset Kawasan Techno Park Pelalawan Tahun 2018 2033

\begin{tabular}{|c|c|r|c|}
\hline \multirow{2}{*}{ No } & \multirow{2}{*}{ Tahun } & \multicolumn{2}{|c|}{ Jumlah Kebutuhan Air } \\
\cline { 3 - 4 } & & (m3/hari) & (I/detik) \\
\hline 1 & 2018 & 175,4 & 2,03 \\
2 & 2023 & 218,14 & 2,52 \\
3 & 2028 & 263,4 & 3,05 \\
4 & 2033 & 311,81 & 3,60 \\
\hline
\end{tabular}

Sumber :

Analisa BPP Teknologi, Nopember 2015

\subsection{Pentahapan kapasitas desain Pilot Plant Pengolahan Air}

Pentahapan perencanaan kapasitas ditetapkan agar pembangunan instalasi bersifat ekonomis dan sesuai dengan kebutuhan air yang diperlukan masyarakat yaitu perkembangan kapasitas dilakukan per 5 tahunan. Untuk penentuan kapasitas instalasi menurut peraturan Departemen Pekerjaan Umum tahun 2009, perlu diperhitungkan adanya kehilangan air untuk memenuhi kebutuhan jika ada kebocoran pada pipa selama distribusi ke kekonsumen dan keperluan instalasi sebesar 20\%, serta adanya fluktuasi kebutuhan konsumen pada waktu tertentu sehingga ditetapkan kapasitas desain installasi pengolahan air minum sama dengan kebutuhan maksimum dengan faktor 1,15 dari kebutuhan rata-rata,

Berdasarkan jumlah kebutuhan air zona Pendidikan dan Riset dan peraturan tersebut maka telah dihitung kehilangan air, kebutuhan rata-rata, kebutuhan air maksimum dan ditetapkan kapasitas instalasi seperti tabel 6 berikut.

\subsection{Sumber Air Baku Dan Kualitasnya}

Berdasarkan studi literatur dan data sekunder, serta informasi dari instansi pemerintah daerah, masyarakat, serta tokoh-tokoh masyarakat di sekitar kawasan Techno Park diketahui bahwa sumbersumber air yang telah dimanfaatkan untuk pemenuhan kebutuhan air minum/bersih masyarakat di sekitar kawasan Techno Park berasal dari sungai Kampar, air permukaan sekitar pemukiman penduduk, air tanah dalam dan penyediaan air minum. Sedangkan BPAB (Badan Pengelola Air Bersih) untuk melayani penyediaan air minum masyarakat menggunakan sumber air baku yang berasal dari air sungai Kampar. 
Danau Tajwid akan dimanfaatkan sebagai daerah pariwisata sehingga Pemerintah Daerah menentukan program untuk mengelola sumber air yaitu dengan mempertahankan debit serta kualitasnya. Kegiatan ini berupa pembuatan semacam pembatas di yang berlokasi antara sungai Kampar dan danau Tajwid serta ditetapkannya aturan bahwa nelayan tidak boleh mengambil ikan di danau Tajwid. Selain itu telah dibangun jalan di pinggir danau yang ditujukan untuk pengembangan wisata di lokasi tersebut. Pulau Tajwid-nya atau tanah dataran dilingkungan danau Tajwid, rencananya akan dijadikan wilayah konservasi hutan sehingga keaslian hutan di wilayah tersebut tetap terjaga.
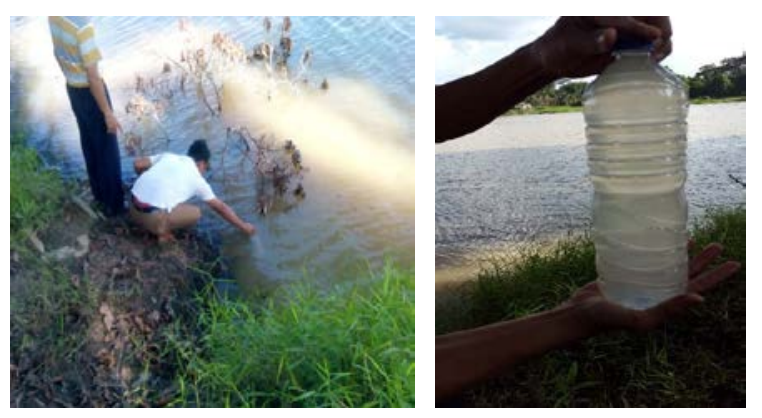

Gambar 2. Sampling air S.Kampar

Danau Tajwid mendapat aliran dari sungai Kampar sehingga jumlah debit aliran air yang masuk tergantung dari sungai tersebut. Untuk mengetahui kualitas air di di sungai Kampar dan Danau Tajwid, maka telah dilakukan sampling dan dan analisa terhadap kualitas air. Lokasi pengambilan sampel air yaitu di S Kampar di ambil di intake BPAB dan Danau Tajwid berada di daerah yang lebih ke hulu, yaitu sebelum pertemuan dengan anak Sungai Segintil.

Dari hasil analisa laboratorium kedua sumber tersebut yang telah dibandingkan dengan Peraturan Menteri Kesehatan Republik Indonesia Nomor 416/MENKES/PER/IX/1990 ${ }^{1)}$, diketahui bahwa bahwa kualitas air sungai Kampar di Danau Tajwid lebih baik dari pada di kualitas air S. Kampar dititik In-take BPAB (lihat tabel 7). Untuk parameter kekeruhan dan warna terlihat bahwa kualitas air Danau Tajwid jauh lebih bagus, tetapi untuk kandungan zat organiknya ternyata air sungai kampar di titik Intake BPAB yang lebih baik.

Tabel 6. Perencanaan Kapasitas Desain Instalasi Pengolahan air Zona Pendidikan dan Riset Tahun Kawasan Techno Park Pelalawan 2018 -2033

\begin{tabular}{|c|l|c|c|c|c|c|}
\hline NO & \multicolumn{1}{|c|}{ URAIAN } & \multirow{2}{*}{ SATUAN } & \multicolumn{4}{|c|}{ TAHUN PERENCANAAN } \\
\cline { 4 - 7 } & & & $\mathbf{2 0 1 8}$ & $\mathbf{2 0 2 3}$ & $\mathbf{2 0 2 8}$ & $\mathbf{2 0 3 3}$ \\
\hline 1 & Penduduk Yang Dilayani & jiwa & 5516 & 5968 & 8099 & 9512 \\
2 & Kebutuhan Air & $\mathrm{I} / \mathrm{dt}$ & 2.03 & 2.52 & 3.05 & 3.61 \\
3 & Kehilangan Air & $\mathrm{I} / \mathrm{dt}$ & 0.41 & 0.50 & 0.61 & 0.72 \\
4 & Kebutuhan Air Rata2 & $\mathrm{I} / \mathrm{dt}$ & 2.44 & 3.03 & 3.66 & 4.33 \\
5 & Kebutuhan Air Maks(F=1.15) & $\mathrm{I} / \mathrm{dt}$ & 2,80 & 3,48 & 4,21 & 4,98 \\
6 & Kapasitas Perencanaan Instalasi & $\mathrm{I} / \mathrm{dt}$ & 3 & 3,5 & 4,5 & 5 \\
\hline
\end{tabular}

Sumber: Analisa BPP Teknologi, Nopember 2015

Sementara itu untuk parameter total coliform keduanya mempunyai nilai yang sama dan jauh melampaui baku mutu Peraturan Menteri Kesehatan Republik Indonesial Nomor 416/MENKES/ PER/IX/1990 tentang kualitas air bersih.

Tabel 7. Hasil Analisa Laboratorium Air Danau Tajwid Dan S Kampar (Titik In-Take BPAB)

\begin{tabular}{|c|l|c|c|c|c|}
\hline No. & $\begin{array}{c}\text { Parameter } \\
\text { (Satuan) }\end{array}$ & Unit & $\begin{array}{c}\text { Air D. } \\
\text { Tajwid }\end{array}$ & $\begin{array}{c}\text { Air } \\
\text { Intake } \\
\text { BPAB }\end{array}$ & $\begin{array}{c}\text { Baku } \\
\text { Mutu*) }\end{array}$ \\
\hline 1 & Kekeruhan & NTU & 5,6 & 52 & 25 \\
\hline 2 & Warna & TCU & 71 & 251 & 50 \\
\hline 3 & Zat Organik & $\mathrm{mg} / \mathrm{l}$ & 17,2 & 7,6 & 10 \\
\hline 4 & $\begin{array}{l}\text { Total } \\
\text { Coliform }\end{array}$ & (jh/100ml & 240 & 240 & 10 \\
\hline
\end{tabular}

Sumber:

Laboratorium Departemen Kesehatan, Pekanbaru dengan baku mutu Menkes RI No. 416/MENKES/PER/IX/1990

Untuk mengetahui kualitas air tanah lebih rinci maka telah dilakukan pengambilan sampel air tanah di 2 lokasi di kelurahan Langgam yaitu di Kantor Kecamatan Langgam dan di Pasar Langgam. Sampel air telah dianalisa di laboratorium Departemen Kesehatan, Pekanbaru, Riau. Secara umum keduanya menunjukkan hasil analisa kualitas air yang sangat baik, yaitu memenuhi syarat baku mutu untuk semua parameter yang ada (21 Parameter) sesuai dengan Peraturan Menteri 
Kesehatan Republik Indonesia Nomor 416/MENKES/ PER/IX/1990 tentang kualitas air bersih.

Berdasarkan data dari pelaksana pengeboran air tanah di lokasi tersebut maka diketahui jumlah debit air yang dapat dimanfaatkan sekitar 2,5 liter/ detik dengan kedalaman sekitar 150 meter. Jenis sumur bor semacam ini banyak terdapat di kelurahan Langgam yang telah dimanfaatkan penduduk untuk kebutuhan sehari-hari.

3. RANCANGAN PILOT PLANT PENGOLAHAN AIR MINUM

\subsection{Perencanaan Proses Pengolahan Air}

Proses pengolahan di instalasi pengolahan air harus disesuaikan dengan sumber air bakunya yang terdapat di lokasi perencanaan. Berdasarkan data survai di lapangan, ada 2 sumber air yang dapat digunakan sebagai alternatif air baku untuk penyediaan air minum di zone pendidikan dan riset yaitu sumber air tanah dan air sungai Kampar (lokasi intake UPT AB). Sumber air sungai kuantitas dan kontinyuitas cukup untuk digunakan sebagai sumber air baku, sedangkan sumber air tanah kuantitasnya terbatas dan perlu penelitian lagi untuk mengetahui kontinyuitasnya.

Sedangkan perencanaan instalasi pengolahan air bersih yang direncanakan terdiri atas 2 alternatif teknologi sistem pengolahan air, yaitu:

1) Pengolahan air dari sungai Kampar (intake UPT $A B$, sungai Kampar)

Inovasi teknologi untuk pengolahan air yang akan dipilih bersifat ramah lingkungan dan yang menghasilkan limbah sesedikit mungkin. Sesuai dengan kualitas air baku dari sungai Kampar yang kekeruhannya cukup tinggi terutama pada musim hujan maka dapat dipilih proses pengolahan dengan sistem ultrafiltrasi yang dilengkapi pengolahan pendahuluan. Proses pengolahan pendahuluan tersebut berupa pembubuhan bahan kimia, bak koagulasi, flokulasi dan bak pengendap dan air dari pengolahan ini selanjutnya dapat memenuhi standard kualitas untuk proses pengolahan ultrafiltrasi.

2) Pengolahan air dari air tanah
Air dari sumber air tanah kualitasnya baik sehingga pengolahan sumber air tanah hanya dengan sistem ultrafiltrasi yang tidak memerlukan pengolahan awal (pembubuhan bahan kimia, koagulasi, flokulasi dan pengendapan.

Proses Ultrafiltrasi yang akan digunakan merupakan teknologi penyaringan air dengan menggunakan membran untuk memisahkan senyawa maupun partikel koloid, protein, polutan dari unsur mikrobiologis yang ada pada air baku7). Ukuran membran ultrafiltrasi sangat kecil sehingga dapat memisahkan material tersuspensi, bakteri, virus dan pathogen. Semua partikel dengan ukuran kisaran 0,01 micron sampai dengan 0,1 micron akan dapat terpisah dengan teknologi ultra filtrasi. Tekanan Operasi pada sistem ultra filtrasi dapat digunakan tekanan rendah yaitu antara 0,5 sampai 3 bar. Membran ultra filtrasi dapat dibuat dalam beberapa tipe modul seperti hollow fiber, lembaran rata dan dalam bentuk tabung. Tipe hollow fiber adalah tipe yang paling banyak dipakai karena akan dapat menghasilkan permukaan filtrasi yang besar. Kecepatan filtrasi akan sangat tergantung dari luas permukaan filter. Dengan semakin besarnya luas permukaan filter, maka produktifitas air olahan akan semakin besar.

Walaupun secara teori ultrafiltrasi dapat menahan kontaminan mikrobiologis seperti virus dan bakteri coli, untuk lebih amannya perlu juga ditambah unit desinfeksi, misalnya menggunakan UV.

\subsection{Rancangan Alat Pengolahan Air}

Sesuai dengan pemilihan teknologi yang akan diaplikasikan maka dilakukan rancangan alat pengolahan air dengan proses ultrafiltrasi yang dilengkapi dengan pendahuluan (pretreatment). Pengolahan pendahuluan dirancang terdiri atas tangki dan pompa pembubuhan bahan kimia, static mixer, bak koagulasi, flokulasi dan bak sedimentasi. Sedangkan perancangan proses ultrafitrasi meliputi automatic filter, pompa tekanan tinggi, pompa tekanan tinggi, membran ultrafiltrasi dan ultraviolet sterilisator.

Secara lengkap proses pengolahan Air Dengan Sistem Ultrafiltrasi seperti yang terlihat pada gambar 3 di bawah ini. 


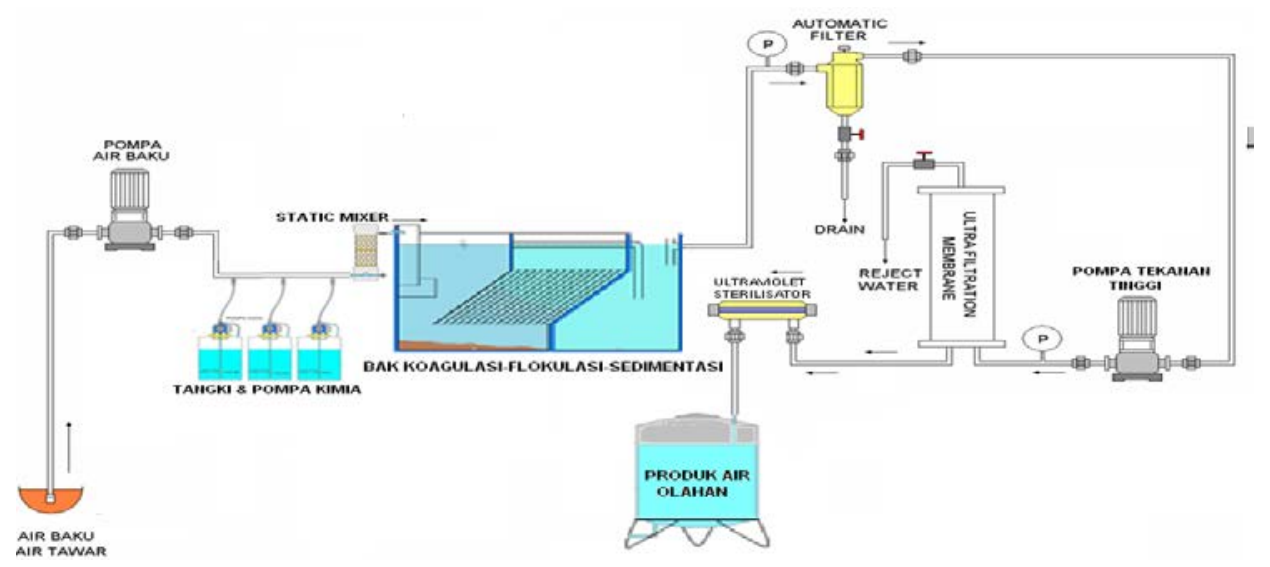

Gambar 3. Proses Pengolahan Air Minum Dengan Sistem Ultrafiltrasi

Secara singkat proses pengolahan adalah sebagai berikut:

Rangkaian unit pengolahan air minum dengan sistem ultrafiltrasi adalah seperti pada gambar 2 , yang terdiri atas unit-unit sebagai berikut:

\section{a. Pompa Air Baku}

Pompa air baku adalah pompa sentrifugal biasa dengan kapasitas yang sesuai dengan kapasitas maksimum dari Unit Pengolah Awal. Pompa air baku minimal mempunyai daya tarik minimal 30 meter dan daya dorong 50 meter. Pompa air baku kedua digunakan untuk memompa air baku untuk diolah dalam unit pretreatment.

Unit-unit yang harus dilalui oleh air baku adalah proses aerasi, bak flokulasi dan koagulasi dan filter kantong. Sebagai contoh kasus dalam proses pengolahan awal (Kapasitas $10 \mathrm{~m}^{3} /$ hari) kehilangan tekanan sekitar 1-2 bar. Sehingga minimal pompa air baku harus bertekanan 4 bar, sehingga pada saat memasuki unit ultrafiltrasi tekanan masih tersisa sekitar 2 bar.

\section{b. Pompa Dosing}

Dalam sistem pengolahan air permukaan dengan sistem ultrafiltrasi ini, dibutuhkan pompa dosing, yakni untuk pembubuhan kapur yang berfungsi untuk mengatur $\mathrm{pH}$ dan pembubuhan tawas sebagai proses flokulasi yang ada di dalam air baku. Pompa kimia ini terhubung dengan pengaman tekanan pada pompa air baku sehingga kontrol pada pompa kimia ini saling terkait terhadap pompa air baku tersebut.

c. Bak Flokulasi, koagulasi dan Sedimentasi

Bak Flokulasi dan bak koagulasi adalah bak untuk mencampur dan mereaksikan larutan kapur dan tawas dengan air baku agar partikel-partikel padat tersuspensi, zat warna, koloid dan lain-lain yang sukar mengendap dapat menggumpal menjadi besar (flok\} dan berat sehingga kecepatan pengendapannya lebih besar. Sedangkan zat alkali dan zat pembantu koagulan berfungsi untuk mengatur $\mathrm{pH}$ agar kondisi air baku dapat menunjang proses flokulasi, serta membantu agar pembentukan flok dapat berjalan dengan lebih cepat dan baik. Bak sedimentasi berfungsi untuk mengendapkan flok yang sudah terbentuk pada proses tersebut.

d. Pompa Tekanan Tinggi

Pompa feed berfungsi untuk mengalirkan air dari Catridge filter menuju proses ultrafiltrasi. Untuk menembus membran ultrafiltrasi maka diperlukan tekanan yang cukup agar proses berjalan optimal.

\section{j. Unit Ultrafiltrasi}

Unit ultrafiltrasi merupakan peralatan utama dari sistem pengolahan air secara keseluruhan. Unit ini terdiri dari selaput membran yang digulung secara spiral dengan pelindung kerangka luar (vessel) yang tahan terhadap tekanan. Kapasitas tiap unit unifiltrasi bermacam-macam tergantung disain yang diinginkan. Daya tahan membran ini sangat tergantung pada proses pengolahan pendahuluan. Jika pengolahan pendahuluan baik, maka membran ini dapat tahan lama.

k. Panel Kontrol

Seluruh rangkaian listrik dalam sistem ultrafiltrasi ini berada dan berpusat dalam satu unit yang disebut panel kontrol. Panel ini dilengkapi dengan indikator-indikator tekanan dan sistem otomatis. Apabila tekanan pada membran telah mencapai nilai maksimum, maka dengan sendirinya switch aliran listrik menghentikan suplainya dan seluruh sistem juga berhenti. Dalam keadaan seperti ini kondisi membran harus diamati secara khusus dan apakah sudah saatnya harus diganti.

I. Tangki Penampung Air Olahan

Air hasil pengolahan sistem ultrafiltrasi ini ditampung pada tangki penampung air olahan. Jumlah tangki penampung disesuaikan dengan kebutuhan. Tangki ini terbuat dari bahan fiberglass atau beton. Tangki penampung ini diletakkan ditempat yang agak tinggi $(1 \mathrm{~m}$ atau lebih) agar supaya air hasil olahan tersebut dapat 
dialirkan secara gravitasi atau jika head nya kurang untuk mengalirkan air perlu disediakan pompa.

m. Tangki Bahan-Bahan Kimia

Tangki bahan kimia terbuat dari fiberglass atau bahan beton agar tidak korosif. Bahan-bahan kimia utama adalah tawas, kapur, kaporit, anti penyumbatan dan anti pengerakkan.

\section{n. Sistem Jaringan Perpipaan}

Sistem jaringan perpipaan terdiri dari empat bagian, yaitu jaringan inlet (air masuk), jaringan outlet (air hasil olahan), jaringan bahan kimia dari pompa dosing dan jaringan pipa pembuangan air pencucian. Sistem jaringan ini dilengkapi dengan keran-keran sesuai dengan ukuran perpipaan. Bahan pipa PVC tahan tekan, seperti rucika. Sedangkan keran yang dipakai adalah keran tahan karat terbuat dari plastik.

Secara singkat proses pengolahan adalah sebagai berikut:

Air dari sumber dipompa dan dialirkan ke bak penampung, selanjutnya dipompa ke unit pretreatment untuk menghilangkan padatan tersuspensi. Kalau pada sistem konvensional, unit pre-treatment ini menggunakan bak pengendap yang prosesnya memerlukan penambahan bahan kimia koagulan dan flokulan.

Setelah melalui proses pendahuluan maka air dialirkan ke catridge filter seperti pada gambar 2 yang merupakan teknologi baru untuk memisahkan kotoran maupun lumpur dalam air baku. Air dari proses pendahuluan dipompa kedalam filter ini secara kontinyu untuk dilakukan proses filtrasi.

Setelah proses itu, air selanjutnya dipompa masuk ke membran ultra filtrasi. Yang paling banyak dipakai adalah membran tipe hollow fiber. Di unit membran ini dapat diset besarnya air produk dan besarnya air rijek. Semakin besar rijek, maka kualitas air produk akan semakin baik. Apabila filter sudah kotor, tekanan dalam filter akan naik sampai tingkat tertentu sesuai pengaturan. Pada saat tekanan sudah mencapai tingkat tertentu, maka saklar otomatis akan bekerja menggerakkan motor untuk melakukan backwash. Pada saat backwash, lumpur atau padatan tersuspensi yang menempel pada bagian filter akan terdorong keluar bersama aliran backwash. Proses filtrasi dan backwash berjalan secara otomatis, sehingga akan sangat mempermudah kerja dari operator.

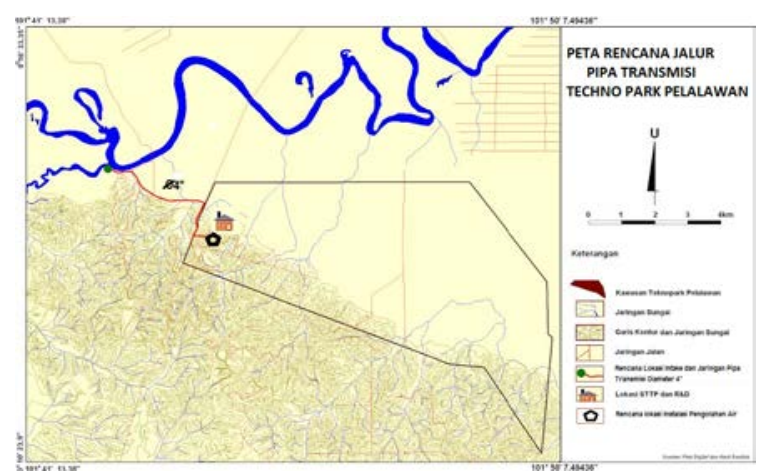

Gambar 4. Peta Rencana Jalur Pipa Transmisi Techno Park Pelalawan

Proses backwash pada sistem ultra filtrasi dapat diatur secara manual atau secara automatis. Pengesetan backwash secara manual dapat dilakukan seperti pada filter konvensional dengan sistem buka tutup katup apabila penurunan tekanan filter sudah tinggi. Pengesetan backwash secara automatis dapat dilakukan dengan memasang alat kontrol tekanan dan katup otomatis. Apabila tekanan sudah mencapai angka tertentu, maka proses backwash akan berjalan dengan sendirinya.

\subsection{Perencanaan Pipa Transmisi Air Baku}

Instalasi pengolahan air direncanakan akan dibangun pada lokasi dengan elevasi yang tertinggi agar dapat dialirkan dengan gravitasi atau dapat mengurangi penggunaan pompa. Sesuai dengan topografinya maka instalasi tersebut direncanakan akan dibangun di zona pendidikan Kawasan Techno Park Pelalawan di kecamatan Langgam.

Pipa transmisi dibutuhkan sebagai sarana untuk mengalirkan air baku dari sumbernya ke instalasi pengolahan air. Sesuai dengan hasil survai maka sumber air baku yang berasal dari air tanah dan yang terletak di kelurahan Langgam di zone Pendidikan tidak memerlukan pipa penyalur atau pipa tranmisi yang panjang. Walaupun demikian tetap dibutuhkan pompa penghisap dan pompa pengalir air baku ke instalasi pengolahan air.

Sedangkan pengaliran sumber air baku dari air permukaan seperti sungai Kampar yang berjarak 4,89 km dari rencana lokasi instalasi diperlukan pipa transmisi dengan jalur pipa yang direncanakan mengikuti jalan raya serta dilengkapi pompa penyalur air baku.

Untuk pembangunan instalasi supaya lebih ekonomis maka dari awal pipa transmisi dibangun dengan kapasitas air yang akan dialirkan sebesar 5 I/dt sesuai dengan kapasitas perencanaan pada akhir tahun perencanaan atau tahun 2033. Berdasarkan perhitungan maka diameter pipa sebesar $15 \mathrm{~cm}$ atau 6 inch dengan peta jalur pipa transmisi sampai instalasi yang direncanakan dapat dilihat pada gambar 4. Peta Rencana Jalur Pipa Transmisi Techno 
Park Pelalawan berikut 6). Jika pipa transmisi dari sungai Kampar belum dibangun agar dapat menyediakan debit yang cukup sesuai dengan kebutuhan ke dua zona tersebut maka untuk sementara air baku instalasi akan diambil dari air tanah sampai sumber air dari sungai Kampar tersedia.

\section{KESIMPULAN DAN SARAN}

\subsection{Kesimpulan}

Berdasarkan uraian diatas, maka dapat disimpulkan :

1) Proyeksi jumlah penduduk yang akan dilayani penyediaan air minumnya di zona pendidikan dan zona riset sampai tahun 2033 disesuaikan dengan master plan kawasan Techno Park.

2) Perhitungan jumlah kebutuhan air didarkan atas jumlah proyeksi penduduk dan standard yang sesuai dengan peruntukan di kedua zona tersebut.

3) Pentahapan desain dilakukan 5 tahunan agar pembangunan instalasi lebih ekonomis dengan kapasitas desain pada tahun 2033 sebesar 5 liter/detik.

4) Instalasi pengolahan air yang direncanakan dibangun di zona pendidikan kecamatan Langgam menggunakan sistem ultrafiltrasi yang terdiri atas unit pengolahan penduhuluan dan pengolahan sistem ultrafiltrasi.

5) Sumber air baku instalasi pengolahan air terdiri dari sumber sungai Kampar dan sumber air tanah. Panjang pipa transmisi dari sumber air baku sepanjang 4,89 km dengan diameter 6 inch sesuai dengan jaringan jalan.

\subsection{Saran}

1) Jika rencana akan diimplementasikan, rencana ini perlu dilakukan cek ulang dan diperbaiki jumlah penduduknya bila ada perubahan pada master plan kawasan Techno Park, yang selanjutnya dihitung kembali jumlah kebutuhan air sesuai dengan perbaikan tersebut.

2) Perhitungan kapasitas desain instalasi pengolahan air minum juga harus disesuaikan dengan jumlah kebutuhan air yang sudah direvisi.

3) Dalam penggunaan sumber air tanah sebagai sumber air baku instalasi pengolahan air maka diperlukan survai geolistrik dan pumping tes untuk menentukan kelayakannya sebagai sumber air baku dengan pemilihan sumber air yang lokasinya terdekat dengan instalasi.
4) Panjang pipa transmisi perlu disesuaikan lagi jika ada pembangunan jalan raya yang jaraknya lebih singkat.

\section{DAFTAR PUSTAKA}

- Anonim. 1990. Peraturan Menteri Kesehatan RI, Nomor 416/MENKES/ PER/IX/1990 tentang kualitas air bersih.

- Laporan Master Plan Pengembangan Wilayah Kawasan Techno Park Pelalawan, BPPT, 2015 dan Master Plan ST2P, 2013.

- Ditjen. Cipta Karya 1998, Kebutuhan Air Minum Domestik.

- Dayan Anto, 1976, Pengantar Metoda Statistik jilid I, PT. Pustaka LP3S, Jakarta.

- SK - SNI 03-7065-2005 Kebutuhan Air Bersih

- Peta Geologi Lembar Kabupaten Pelalawan Skala $1: 250.000$.

- Kawamura, S. 2000. Integrated Design of Water Treatment Facilities. Second Edition. New York : John Willey and Sons. 
